\begin{tabular}{|c|c|}
\hline 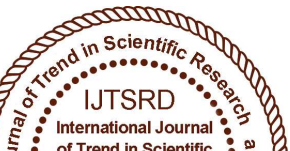 & $\begin{array}{l}\text { International Journal of Trend in Scientific } \\
\text { Research and Development (IJTSRD) }\end{array}$ \\
\hline 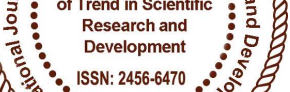 & International Open Access Journal \\
\hline 000 & ISSN No: 2456 - 6470 | www.ijtsrd.com | Volume - 2 | Issue - 3 \\
\hline
\end{tabular}

\title{
Trafficking of Women and Girls for Commercial Sexual Exploitation: An Analysis on Impact of Violence in Kolkata's Brothel
}

\author{
Awkash Kumar \\ Ph.D. Research Scholar, Centre for Security Studies and Research, \\ School of International Studies, Central University of Gujarat, Gandhinagar, India
}

\begin{abstract}
Trafficking in women girls and children is an organised crime that brutally exploited them for numerous purposes. Trafficking for the prostitution is the worst form of exploitation where they have to face numbers of violence, which has a severe impact on their physical, mental and health development. Thus, the primary objective of this paper is to explore the kinds of violence faced by the trafficked prostitutes in Kolkata's brothel and what are the impact of this violence on prostitutes. Numbers of trafficked women and girls are currently working in the brothel of Kolkata. 25 women and girls were interview for this study. What it has is analysed in the survey that they come from marginalised community, less educated and mostly unmarried. For surviving they have to face some violence such as physical and sexual abuse, beaten, locked in a room without food, tortured brutally and sometimes threaten to murder by their owners, madams, traffickers as well as from their clients in their different stages. The study also found that they have a direct impact of violence regarding the loss of weight, several marks on their body, affected by the sexually transmitted disease, unwanted pregnancy and several abortions.
\end{abstract}

Keywords: Trafficking, physical and sexual exploitation, impact of trafficking

\section{Human Trafficking}

Trafficking of human beings is an organised crime that brutally exploits men, women and children for various purposes, which may include sexual exploitation, forced labour, organ trade, bonded

labour and much more. Trafficking of women and girls for the prostitution has absolute negative, legal and practical consequences for their rights. Today where in a society full gender equality exists, at the same time women as a commodity that can be bought and sold for sexual exploitation cannot be accepted. According to researchers around the world, it has been found that women in prostitution have the highest rates of rape and homicide (around 50 percent of deaths) of any groups of women, and they also suffer injury equivalent to victims of state-sponsored torture (Farley, et al., 2003). Through this paper, an attempt has been made to explain the scenario of trafficked prostitute in India with a particular reference to Kolkata's brothel. Thus the papers seek to understand the types of violation faced by the sex workers at their workplace and the impact of sexual as well physical violence on them. Finally, the paper ends with conclusion and discussion.

Trafficking is considered as one of the fastest growing criminal activity after arms trafficking, and as a second most profitable criminal enterprise, which generates an estimated 32 billion dollars every year (Hagopian, 2015). According to The International Labour Organisation (ILO) around 20.9 million people are trapped in forced labour or human trafficking. Around 18.7 million people are being forced to labour work in the private economy, exploited by individuals or enterprises. Out of these, 4.5 million are in forced sexual exploitation, and 14.2 million in forced labour exploitation in activities such as agriculture, construction, domestic work and manufacturing (ILO, 2012). The United Nations (UN) 
estimates that approximately 2.5 million people are being trafficked around the world, and around 80 percent of them are women and children (UNODC, 2008).

According to estimated report, 53 percent of trafficked victims are involved in sexual exploitation, and around 40 percent in forced labour which includes exploitation in agriculture, horticulture, construction, textile production in sweatshop conditions, catering and restaurants, entertainment services and domestic servitude(UNODC, 2015). As per the review article producing evidence from different studies acrosssomecountries indicates that 20 to 40 percentof females are engaged in the commercials ex industry, entered in this field in their adolescentage at around 16 years of age(Silverman, et al., 2011). In a study conducted in Indiaestimatedthat 24 lakh women in prostitution lived in thered light areas with 52 lakh children, and also pointed out that 45 percent of the girls belonged to the category of neglected juveniles at the time they entered into the prostitution(Desai, 2003-2007). Almost 80 percent of all global trafficking is for sexual exploitation, with an estimationthat 12 million children are bought and sold into sexual slavery every year, and India is the poisonous hub(Peebles, 2013). In India, millions of people trafficked every year. It can be estimated that every eight minutes a child goes missing in the country. Almost 35,000 children were officially reported missing in2011, over 11,000 of them were from West Bengal itself, how every it was thought that only 30 percent of the case is reported(Peebles, 2013). The number of women and children in sex work in India is estimated to be between 70,000and 1 million.Moreover,in which around 30 percent are below 20 years of age. Nearly 15 percent sex workers are between 15 to 18 years old.Aroughestimatethat 2 million children are abused and forced into prostitution(Nair \& Sen,2005). In other studies of trafficking and female sex workers have reported that between 19 to 59 percent of adult women engaged in sex work trafficked as minors. The survey also indicates that trafficking into sex work associated with higher frequencies of sexual and physical violence, unprotected sex, alcohol use and risk of HIV (George \& Sabarwal, 2012).

In the year2000, the United Nations in its Protocol to Prevent, Suppress and Punish Trafficking in Persons adopted in Palermo defines human trafficking in Article 3 as: "Trafficking in persons" shall mean the recruitment, transportation, transfer, harbouring, or receipt of persons, by means of threat or use of force or other forms of coercion, of abduction, of fraud, of deception, of the abuse of power or of a position of vulnerability or of the giving or receiving of payments or benefits to achieve the consent of a person having control over another person, for the purpose of exploitation. Exploitation shall include, at the minimum, the exploitation of the prostitution of others or other forms of sexual exploitation, forced labour or services, slavery or practices similar to slavery, servitude or removal of organs"'(UN, 2000).

The adoption of this definition was a significant development because it provides general guidance to different actors, such as scholars, governments, nongovernmental organisations (NGOs) to examine and respond to trafficking.

In India, the National Crime Record Bureau (NCRB) has defined human trafficking as a "group of crimes involving the exploitation of men, women and children for financial gain, which is a violation of fundamental human rights"(Kamal, Rajasekaran, \& Kumar, 2011). According to Indian Constitution, the traffic in persons means "buying, selling, disposing of human beings in the same way as the goods and chattels are dealt with" (Nirmala, 2013). In this way, although the term slavery has not been expressly used in Article. 23(1) nonetheless the use of expression "trafficking in human being" undoubtedly includes the "slavery", in its traditional sense, with its ambit and scope. Thus, the expression traffic in human beings covers the cases of traffic in women and children for immoral or other purposes. Parliament has enacted Suppression of Immoral Traffic (Prevention) Act, 1956, for the purpose punishing those who are engaged in the business of trafficking in women and girls for an immoral purpose.

According to studies, it has been revealed that more than 40 percent of persons investigated for human trafficking in India were females (UNODC, 2014). Every year more than 5,000 to 10,000 Nepalis and Bangladeshi women and girls are being trafficked for the purpose of sexual exploitation and work in several brothers in India. However, it has also been estimated that 90 percent of India's sex trafficking is internal only 10 to 20 percent trafficking for sex industry is done internationally (Chaudhury, 2012). Around 60 percent of the sex workers and brothel owners in Mumbai and Kolkata are Nepalis. 
The concept of human trafficking refers to the criminal practices of exploiting people by treating them as commodities for profit. Even after they are trafficked, victims are subjected to long term exploitation. Trafficking, both for commercial sexual exploitation and for non-sex based exploitation is a transnational and complex challenge; it is an organised criminal activity, an extreme form of human right violation and an issue of economic empowerment and social justice. The trafficking of women and girls cause untold miseries as it violates the rights and dignity of the individual in several ways. Assuming measurement of trafficking of women and girls in Kolkata's brothel is hard as there is fewer data available.

\section{Objectives/Research Questions}

The major objectives of this research are to explore the extent of exploitation on trafficked victims in the brothel of Kolkata. Moreover, to examine the impacts of violence on their physical, mental as well as health status.

\section{Methodology}

The interview of trafficked victims was carried out in two stages.

\section{Stage I: Information from call girl}

In the Kolkata city, I contacted my friend he was in contact with a call girl named Shajida who belongs to Bangladesh; she was staying in Kolkata and acting as a call girl. So he fixed my meeting with her. I explained her my research; she said she would try to help me in my research. She told me the structure of trafficking and prostitution in Sonagachi brothel. As it was difficult for her to meet me every time, so we had a telephonic conversation and she told me about few trafficked girls in a brothel, she explained me about their looks and name and building number so that I can recognise her easily. She also said she would keep informing her if can find out something else related to my work.

\section{Stage II: Interview with trafficked victims in brothel}

After getting some information from her. I visited the place named "Sonagachi" the brothel area of Kolkata. After reaching there, I was standing before the building she Shajida mentioned. I was wondering for any pimp (male) as I was alarmed to go with any male pimp rather going alone. Finally while talking to a shopkeeper, I found one pimp he asked me what kind of girl you want; I said him "Nepali girl" because I wanted to meet that girl, she was from Nepal He took me in that building. On the first floor, there were many of girls standing in the corridor and calling me to come with her. After going inside, I told him her name, so he took me the front of her door. After talking to her she took me in her private room, and I paid her Rs. 300 for 30 minutes. Initially, she was behaving me as her client, but when I told her my purpose of visit, she started abusing me in Bangla language and tried to escape. I requested her not to leave and assured her that there wouldn't be any harm to you. I just came to talk to you, after some time she was calm and started talking to me. I asked her to help me to find other trafficked women those are working in a brothel. In the beginning, she totally refused due to fear, but after few meetings, she agreed to help me in my research on the condition that I will never speak up her name. So, she introduced me to other women like her in the brothel. I interview all trafficked women acting as a client and for each meeting I had to pay them some amount because further, they have to pay their rent to the brothel owner.

While interviewing sex workers, World Health Organisation (WHO) ethical and safety recommendations for interviewing trafficked women was followed strictly ${ }^{1}$. It was also difficult for her to locate always trafficked girls because those trafficked victims are strictly instructed not to disclose their original identity. So sometimes I had to interview those girls, she is not exactly trafficked, but according to them migration and lack of awareness were the reason for becoming a prostitute. All the interview lasted for around 30 to 35 minutes. I interviewed around 45 women with a semi-structured questionnaire to know the cause and consequences of trafficking. All the interview conducted in the Hindi language during the year 2012-2014. I interviewed 25 trafficked women in which 16 women were less than 20-25 years old, five women were 15-20 years old, and another four were 25-35 years old.

\section{Trafficking of women in sex industries in Kolkata brothel}

For ages, the commercial sex trade has been the chief destination for trafficked girls in India (Nair \& Sen,

\footnotetext{
${ }^{1}$ Zimmerman, Cathy, Charlotte Watts, WHO ethical and safety recommendations for interviewing trafficked women, 2003.
} 
2005). India is listed on the Tier II list of the United Nations which includes countries which have failed to combat human trafficking. India also continues to be a source, destination and transit country for forced labour and sex trafficking. According to the Ministry of Women and Child Development, India has nearly 2.5 million prostitutes in nearly 300,000 brothels in 1,100 red-light areas across the country (Tiwari, 2013). Historically, prostitution is considered as a part of Indian society where women were engaged in the trade viewed as entertainment workers, businesswomen, and servers of gods. Many of the social and religious rituals had built in the role of the prostituted women. Thus a legitimate space had been created for them. During the time of British India, the colonial administration used them to relieve sexual tensions of the military, and at the same time, they were stripped of all their legal and social rights (Dasgupta \& Sinha, 2011). At Sonagachi within a few square kilometre, more than 10,000 women and girls sell their body where thousands of men visit daily. Many of them were trafficked from Nepal, Bangladesh and rural areas of India. The number of prostitutes is of rapid growth as a result of trafficking of women and girls are on the increase. According to the statistics from the Crime Investigation Department (CID) trafficking cases has nearly doubled from 4,621 in 2008 to 8,598 cases in 2010 (Ananya, 2012).

\section{Profile of trafficked women and girls}

Women and girls are being trafficked to brothel from various parts of the country as well as internationally from Bangladesh and Nepal. There are multi-casual factors for their trafficking. During an interview with them, they cited a wide range of factors such as poverty, unemployment, lack of awareness and about their rights and domestic violence that pushed them towards trafficking. From their response, it was clear that most of the women and girls were lured through false promises of employment, love and marriage. Once they are into trafficker's hand, they sell them to brothels. The majority of victims became aware of their real work when they reach their destination. Many of responded that in the case of marriage and love, for few days they were living with the traffickers. He treated them as their partner and tried to train them to look modern with dressing sense and there looks. Soon after they look like a modern girl, she reaches brothel. After knowing the real purpose of their migration from their origin if she refuses to act like a prostitute, they had to face various types of violence. They are locked in a room without given proper foods, beaten by owner/madam and raped sometime. They were strictly instructed not to go out without informing the madam and never disclose their identity before any strangers. This kind of violence has lots of impacts on their physical, mental and health status. Interviewing about their family members, they mentioned that they never went back to their homes again, and many of them are not in contact even.

I found that the majority of women were significantly younger, most of these were below the age of 25 years old. Only two or three of them were above the age of 30 . One very important thing I found that around 70 to 75 percent of girls were the age of 20 years old. When I asked them about the age criteria of recruitment they replied that as young ones are more attractive and virgin, the owners and traffickers always prefer them and they get more opportunity to earn more money by selling young girls. Those who are an elder, they are never given preference before youngers. The client always prefers small girls for sexual purposes. The elder prostitutes sometimes due to their low income are not able to pay rent for their room, they are being kicked out by the owner, and then they start working as a street prostitute as they have no any other options and opportunities.

The majority of those trafficked girls and women are unmarried. Some of them were married to the traffickers, but in actual that was fake marriages, they do not have any document to proof their marriage. I could not interview any pimp, owner and traffickers but tried to know their scenario and their roles from the prostitutes. They said that there are many players in this field including the prostitutes, the pimps who sell the women, owners of escorts and brothels. Sometimes directly or indirectly family members, friends and relatives also become part of trafficking. According to them, brothel owners do not want to buy any old women, married or divorced one because many of customers want virgin girls for their pleasure. And they pay much more amount for young ones than elder prostitutes. So this is an opportunity for the brothel owners to earn more money in a small period.

For example, if a brothel owner buys a girl of 20 years old, they can only use her for 5-6 years (as most of the prostitutes become too older for this business after turning 30 years of age). But if the owner buys a girl below 15 years old, they are in this business for more than ten years. It can be concluded that demand is higher for the young ones. According to a study 
conducted by the United Nations Development Program (UNDP) shows that an average age of girls trafficked from Nepal to India was 14 to 16 years in the 1980s and 10-14 in 1994. And the Asian Development Bank Report indicates that nearby 10,000 women were found in Sonagachi brothel of which approximately 70 percent were from Bangladesh.

(According to one prostitute, she belongs to Bangladesh. When she was only 15 years of age, she was trafficked by giving false promises of jobs. She said her family is poor, traffickers took advantage of her poorness and offered them a good job in India with good earning. She had to come with him for money. For two days he treated her nicely, and next day he tried to commit rape on her. After fulfilling his desire, he sold her to the brothel, in the beginning, she could not understand anything. But when the other girls told her about the place and the prostitution it was too late for her. She was trapped and had no other choice instead of becoming prostitute.)

The Sonagachi is a hub for prostitution; sex workers come from various places. Many of them were not good looking, but many of them were beautiful with white skin, standard height, perfect body figure, among those women most of them were from Nepal, another from them little dark skin girls were forming Bangladesh and other parts of India.

\section{Violation and exploitation faced by victims}

Violence on trafficked victims are very common; it can be assumed that violence is the norms for women in prostitution. They face a wide range aggressions and violence from the traffickers and brothel owners from the day they started their journey in brothel till the end, which includes sexual harassment, verbal abuse, stalking, rape, battering and torture. Studies around the world report that trafficked people are often subject to extreme forms of physical, sexual and psychological abuse and neglect and deprivation (Tommaso, Shima, Strom, \& Bettio, 2009). Sex workers are socially ignored, and prostitution is illegal, and that makes the women in Sonagachi extremely susceptible to extortion, blackmail, rape or murder by a local gangster, pimps and the police. In a research a sex worker mentioned that in the process of selling her body, she was shot five times, knifed 13 times, beaten unconscious several times, her arms and nose was broken, her two teeth knocked out, she lost her child, she was verbally abused and had to spend countless days in jail(Myers-Powell, 2008).

While interaction, one prostitute said:

(This is our daily routine, we became habitual for this kind of brutal behaviour and violence/this is my body but not mine. We are treated here like animals; we have to follow their all instructions if we deny their wordings we have to suffer various violence physical as well as mental.)

According to them, many girls are brought in the brothel in their minor ages; the brothel owner forcefully injects them medicines for their body growth. So after interacting prostitutes in Sonagachi, it was assumed that they undergo with numerous of physical, mental and sexual violence. But according to them, they cannot leave that place willingly or run willingly; they have to face all the difficulties. And if they even try to leave or escape; first if society knows about her they never accept them, and second if apprehended they are brought back to the brothel and have to face the brutal punishment. They have become habitual of this kind of behaviour. They said they do it whatever their owner and pimp says them to do to escape the violent behaviour. After all, they have to stay here so for surviving; they do not have any other option.

\section{Condition of women and girls in brothel}

According to a study trafficked women in brothel lives in a very hazardous environment, may not be the reason of lower hygienic condition, but may be due to clandestine condition, exploitation, the violence they face and lack of access to health care (Zimmerman, Kiss, Houssain, \& Walts, 2009). The living condition of prostitutes was very unhygienic; they were living in a small tiny room for which they have to pay nearby Rs. 3,000 to Rs. 4,000 per month to the brothel owner. From the information collected it was confirmed that they have to sleep with around 8 to 10 customer each day. At the time of any occasion or festival, the intensity of customers is high. But the elder prostitutes do not receive client as the younger one receives. So according to them, the customers are attracted towards their age; they prefer to go with the young and virgin girls below the age of 20 years old. Receiving numbers of clients are closely related to their health. They are very prone for the HIV/AIDS and STR/s, RTIs, unwanted pregnancy and abortion, infertility and cancer resulting from STIs. During the interview, it was found that many times client pay 
more to the owners because want to sex without condoms. This information makes clear that most of the sexual diseases are caused because of unsafe sex. On the other hand, I found one fact that most of the time they also have suffered from unnatural sexual exploitation as per the demand of clients and the pressure of their owners as again the owner charge extra money for unnatural sexual pleasure. Trends of oral, virginal and anal sex are very common among all prostitutes. Many of the interviewers mentioned that they were tortured and burnt by cigarettes, they were threatened to be killed by madams and also got injured their vaginal parts by owners whenever they refused to have sex with two or more persons at a time.

(In her story she said that once her owner was forcing her to have sex with two clients at the same time, and when she refused to do so. Her owner slapped her and pulled her by holding her hairs, he inserted his hand inside her leggings and mashed her vaginal part, and asked her will you go or not? As she said it was very painful and finally unwillingly she had to go with them at the same time.)

Another fact which they showed that majority of trafficked women living there had become drug addicted. Using drug help those women to forget their previous life because they know that it is not possible to get back to their families, and may their family do not accept them back after knowing the fact. So unwillingly they are working thereby accepting all the pains.

\section{Consequences/Impact of Violence}

The impact of prostitution on women and girls is impossible to overestimate. Prostitution facilitates the abuse, rape and murder of women and girls. As we have seen that basic rights of trafficked victims are violated in a wider range, and the impact of violence can be categorised in numerous ways such as physical, mental and psychological. Whenever they refuse to work, they were beaten and left without food. I saw various marks on their body of torture. Regular torture and sleeping with many clients per day affect their personal growth. In the age of only 20, they look like older. Many times they became pregnant. They said that always they for abortion and the abortion is either done in brothel itself or in a small clinic which is again unhygienic. After abortion only for few days, their madam allow them to take proper medicines and again they are pushed into prostitution. During the interview it was found that most of them were pregnant at least once, many of them were pregnant more than once. The unhygienic living condition, their work environment, insufficient physical rest and intense physical and psychological violence leads to illness and suffering among the trafficked women and girls. Fever, backache, sleep disorder, irregular menstruation, stomach and back pain problem, heavy lower abdominal pain during intercourse, bleeding after intercourse, abnormal virginal discharge, burning sensation while passing urine are the most common health problem among trafficked women and girl prostitutes.

In a study of prostitution in nine countries found that the prostitution leads to threat, assault and rape. The result showed that 64 percent of respondents had been threatened with a weapon while in prostitution, 73 percent sexually assaulted and 57 percent were raped. 68 percent of respondents met the criteria for diagenesis of the disorder (Farley, et al., 2003). In an another research it was observed that trafficked women involved in prostitution face high level of physical, sexual and psychological abuses. Around 61.7 percent women face headaches, 60.9 percent stomach pain, 44.2 percent memory problem, 42.5 percent back pain, 35 percent loss of appetite and 35 percent tooth pain (Oram, et al., 2012).

Finally, after analysing those trafficked prostitutes, it was accepted that violence during prostitution affects them in various immediate and long-term ways. Its direct impact is on their education, physical and mental and health. Their whole life changed after coming to the brothel. Many of them are having kids, and with them, the life of their kids is in the dark. They are taking care of their kids inside a brothel, at their studying ages they are watching live porn of their mother. This situation affects them mentally as well physically.

\section{CONCLUSION}

Though after studying it is analysed that the women and girls are pushed into prostitution are more vulnerable for the violation of their rights. In the brothel, they are facing huge violence including rape, assault, torture, locked in a room without food, beaten, etc. Severe and repeated violence in their different stages of life leads to trauma which causes the loss of self-esteem among them and sometimes they do not want to be alive. Trafficked victims usually reported bleeding during sexual intercourse, 
negligence of contraceptive methods, and very less access to health care services. Prostitution has always been a social stigma on them. Lack of self-esteem, deep-rooted anger and frustration, feeling an injustice was clearly visible on their faces. Some trafficked victims continue to be emotionally disturbed by trafficking agents who repeatedly persuade them into the same abusive conditions.

Trafficked victims in the brothel are not only vulnerable to the physical and mental abuse but are also vulnerable at serious risk of transmitting diseases like STDs and HIV/AIDS. As many of time, they are unable to protect them from these disease by not allowing to use condoms by their madams and also by some of the frustrated clients.

In the current scenario, the trafficking of minor girls and women is mostly because of social and economic conditions. Lack of awareness about their rights and education also plays a major role in making them vulnerable to being trafficked. Traffickers sell them in a brothel by assuming that selling them into prostitution is more profitable rather than any other places and also there is fewer chances of being caught as those trafficked prostitutes are not allowed to move outside.

The problem of trafficking of minor girls and women for prostitution is an issue violation of their human rights in a global scenario. It has become very necessary to look at the growing trends of trafficking of victims for sexual exploitation. To prevent and respond trafficking, there is a need for developing appropriate response and more in-depth and systematic research

\section{REFERENCE}

1. Ananya, C. (2012). Human Trafficking an Emerging Crime Syndicate and Bondage to the Society of West Bengal. Academic Journal, 1(8), 117. Retrieved March 13, 2016

2. Chaudhury, A. B. (2012). Trafficking of Women and the Crisis of Identity. Peace Prints: South Asian Journal of Peacebuilding, 4(1). Retrieved February 12, 2016, from http://wiscomp.org/pubn/wiscomp-peace-prints/41/ANASUA.pdf

3. Dasgupta, S. D., \& Sinha, I. (2011). Desiring Motherhood, Selling Sex: Women in Kolkata's Commercial Sex Trade. In R. L. Dalla, L. M. Baker, \& J. DeFrain, Global Perspectives on
Prostitution and Sex Trafficking: Africa, Asia, Middle East, and Oceania (p. 105). Europe: Lexington Books.

4. Desai, M. (2003-2007). Child Protection: Current Status and Recommendation of Strategies for the India Country Program. New Delhi: UNICEF.

5. Farley, M., Cotton, A., Lynne, J., Zumbeck, S., Spiwak, F., Reyes, M. E., . . . Sezgin, U. (2003). Prostitution and Trafficking in Nine Countries: An Update on Violence and Posttraumatic Stress Disorder. Journal of Trauma Practice, 2(3/4), 3374.

6. George, A., \& Sabarwal, S. (2012, October 24). Sex Trafficking, Physical and Sexual Violence and HIV Risk Among Young Female Sex Workers in Andhra Pradesh, India. International Journal of Gynecology and Obstetrics, 119-123. doi:10.1016/j.ijgo.2012.08.019

7. Hagopian, J. (2015, April 18). Global Human Trafficking, a Modern Form of Slavery. Retrieved January 23, 2016, from Global Research Centre for Research and Globalization: http://www.globalresearch.ca/global-humantrafficking-a-modern-form-of-slavery/5377853

8. ILO. (2012). New ILO Global Estimate of Forced Labour: 20.9 Million Victims. Vienna: International Labour Organisation.

9. Kamal, N., Rajasekaran, R., \& Kumar, A. (2011). Crime in India 2011 Compendium. New Delhi: National Crime Record Bureau, Ministry of Home Affairs, Government of India.

10. Myers-Powell, B. (2008). Is Paying for Sex Really Worth It? No. Prostitution Exploits Many Women's Deep Pain. Ebony.

11. Nair, P. M., \& Sen, S. (2005). Trafficking in Women and Children in India. New Delhi: Orient Blackswan.

12. Nirmala, V. (2013). Gender Related Violence with Special Reference to Human Trafficking. International Journal of Advanced Research, 2(2), 834-837. Retrieved January 16, 2016

13. Oram, S., Ostrovschi, N. V., Gorceag, V. I., Hotineanu, M. A., Gorceag, L., Trigub, C., \& Abas, M. (2012). Physical Health Symptoms Reported by Trafficked Women Receiving Posttrafficking Support in Moldova: Prevalence, Severity and Associated Factors. Women's Health, 1-9. doi:10.1186/1472-6874-12-20 
International Journal of Trend in Scientific Research and Development (IJTSRD) ISSN: 2456-6470

14. Peebles, G. (2013, September 6). Children and Women for Sale. Retrieved December 14, 2015, from Counter Punch Tells the Facts, Name the Names:

http://www.counterpunch.org/2013/09/06/children -and-women-for-sale/

15. Silverman, J. G., Raj, A., M, D., Decker, M. R., Coleman, S., Bridden, C., ... Samet, J. H. (2011). Sex Trafficking and Initiation-Related Violence, Alcohol Use, and HIV Risk Among HIV-Infected Female Sex Workers in Mumbai, India. The Journal of Infectious Diseases, S1229-S1234. doi:10.1093/infdis/jir540

16. Tiwari, G. (2013, May 27). Children as Victims of Trafficking in India. Retrieved March 28, 2016, from A Contrario International Criminal Law: http://acontrarioicl.com/tag/prostitution/

17. Tommaso, M. L., Shima, I., Strom, S., \& Bettio, F. (2009, June). As Bad as it Gets: Well-Being Deprivation of Sexually Exploited Trafficked Women. European Journal of Political Economy, 25(2), 143-162.
18. UN. (2000). Protocol to Prevent, Suppress and Punish Trafficking in Persons, Especially Women and Children, Supplementing the United Nations Convention Against Transnational Organised Crime. New York: United Nations General Assembly.

19. UNODC. (2008). Human Trafficking: An Overview. Vienna: United Nations Office on Drug and Crime.

20. UNODC. (2014). Global Report on Trafficking in Persons. Vienna: United Nations Office on Drugs and Crime.

21. UNODC. (2015). 13th United Nations Congress on Crime Prevention and Criminal Justice. Doha: United Nations Office on Drug and Crime.

1) Zimmerman, C., Kiss, L., Houssain, M., \& Walts, C. (2009). Trafficking in persons: a health concern? Network of Scientific Journals from Latin America, 14(4), 1029-1035. Retrieved April 1, 2016, from http://www.redalyc.org/articulo.oa? id $=630116920$ 05 